\title{
Traits of Leaders of Rural Non-governmental Organisations as Predictors of Collaboration Between NGOs and Rural Gmina Offices: Voices from Central Poland
}

\author{
Katarzyna Karolina Zajda ${ }^{1}$ - Slawomir Pasikowski ${ }^{2}$ (D)
}

Published online: 12 June 2018

(C) The Author(s) 2018

\begin{abstract}
Collaboration between non-governmental organisations (NGOs) and public institutions, in accordance with the new public governance model, may contribute to actions by such organisations on behalf of both the co-production and co-construction of social services. The aim of this article is to assess the role of selected traits of NGO leaders in determining the chances of collaboration between NGOs and rural gmina offices in central, postsocialist Poland. The authors present the results of studies on selected subjective determinants of such collaboration, in which 104 leaders of NGOs from 29 rural gminas participated. Five independent research tools were implemented. Logistic regression analysis was used to assess the role of selected traits of NGO leaders in determining the potential for collaboration between NGOs and rural gmina offices. The final model indicates that the potential for collaboration between an NGO and a rural gmina office increases alongside higher levels of education, social competences and locus of control and decreased control ideology among NGO leaders. On this basis, the authors formulate practical conclusions concerning the education of leaders of rural NGOs in post-socialist Poland.
\end{abstract}

Slawomir Pasikowski

slawomir.pasikowski@uni.lodz.pl

Katarzyna Karolina Zajda

katarzyna.zajda@uni.lodz.pl

1 Department of Rural and Urban Sociology, Faculty of Economics and Sociology, University of Lodz, Rewolucji 1905 r. Street No. 41/43, 90-214 Lodz, Poland

2 Department of Educational Studies, Faculty of Educational Sciences, University of Lodz, Pomorska Street No. 46/48, 91-408 Lodz, Poland
Keywords NGO leaders · New public governance · Predictors of collaboration · Poland · Rural areas

\section{Introduction}

Over the last 40 years, a change has occurred in determining the role that non-governmental organisations (NGOs) can play in constructing and providing social services to inhabitants of various territorial units (Lindsay et al. 2014, p. 193). This role has been emphasised in the new public governance (NPG) concept (Morgan and Cook 2014 (eds.); Morgan and Shinn 2014; Osborne et al. 2016; Osborne and Strokosch 2013; Radnor and Osborne 2013; Sørensen and Torfing 2015; Torfing and Triantafillou 2013; Wiesel and Modell 2014). The concept highlights the significance of sectors outside the public sphere in not only providing but also constructing social services (Bryan and Sapeha 2015, p. 250). The social sector is no longer treated (similar to the economic sector) as the less expensive (in relation to the public sector) provider of services and has instead been re-approached (contrary to the economic sector) as possessing the ability to shape the participatory attitudes of citizens in the co-construction and co-production of social services (Morgan and Shinn 2014, p. 6). In other words, citizens and their unofficial associations are becoming, together with NGOs, both the constructors and producers of social services (Fotaki 2011; Pestoff 2012; Pestoff et al. 2012; Powell et al. 2010).

According to NPG, collaboration between public institutions and NGOs is viewed through the prism of its advantages. According to Banyan: 'At the heart of new public governance (NPG) is the notion that partnerships, collaboration and engagement produce qualitatively better outcomes for communities. What one organisation cannot 
accomplish alone, a network may leverage their collective resources and energy for joint action' (2014, p. 101). The determinants of such collaboration can be analysed through an organisational perspective in which focus is placed on the assets of the organisations themselves, as well as an individual perspective centred on the influence of the traits of leaders of public institutions and NGOs in establishing collaboration between them (see Mitchell et al. 2015, p. 688; Unceta et al. 2016, p. 195). These traits can make such collaboration either easier or more difficult.

The aim of this article is to assess the role of selected traits of NGO leaders in determining the chances of collaboration between NGOs and rural gmina offices in central, post-socialist Poland. ${ }^{1}$ These traits include social competences, locus of control, assertive confrontation, openness to experience, education, age and sex. We begin by presenting the social context of collaboration between NGOs and rural gmina offices in post-socialist Poland. This context is constituted by exposure to the LEADER approach and, currently, community-led local development.

\section{Collaboration Between Rural Non-governmental Organisations and Public Institutions in Post- socialist Poland}

In post-socialist countries, the NGO sector is still being shaped and supported by, among other sources, grants from international institutions (Chimiak 2016, p. 52-58; Fagan 2006; Furmankiewicz et al. 2016). Many do not perform any activities due to a lack of resources, a lack of members or disillusionment on the part of existing members with the numerous procedures that must accompany the acquisition and accounting of resources (Działek 2014; Zajda 2017).

Clientelism (understood as the dependence of NGOs from public institutions, including local authorities) still occurs among rural NGOs (Furmankiewicz and MackenWalsh 2016, p. 21). Karolewski (2016, p. 256) pointed out, 'informal mechanisms of interest representation' still dominate in post-socialist states, and not all organisations that have an NGO status are actually independent of public institutions; thus, it is sometimes the case that NGOs, dependent on financial grants, become 'paid lobbyists', as exemplified by leisure time associations, such as local sports clubs.

\footnotetext{
${ }^{1}$ Poland is divided into 16 voivodships (provinces) and 380 powiats (districts), which consist of several to over a dozen gminas. Gminas, as the smallest administrative units, are divided into: 1) urban, which consist of one city or town, 2) urban-rural (which include a town and rural areas) and 3) rural gminas (which do not include a town). The most important public institution in such gminas that manages their development is the gmina office.
}

The initial impulse to establish collaboration (in accordance with the NPG concept) between rural NGOs and public institutions in these states was the implementation of the LEADER approach and, currently, community-led local development. ${ }^{2}$ Studies conducted in post-socialist states (Furmankiewicz 2012; Furmankiewicz and MackenWalsh 2016; Kovach and Kucerova 2006; Macken-Walsh and Curtin 2012; Majerova 2009; Marquardt et al. 2012; Pawłowska 2017; Zajda 2014; Zajda and Kretek-Kamińska 2013) indicate numerous problems associated with intersectoral collaboration between these organisations. In Poland (similar to other countries), local action groups have traditionally been dominated by local power elitesrepresentatives of the public sector (Furmankiewicz and Macken-Walsh 2016, p. 14). However, this does not mean that intersectoral collaboration in accordance with the NPG concept-the co-construction and co-production of social services within the framework of local action groups-is not possible. Indeed, the success of the LEADER approach determined the implementation of community-led local development. Furthermore, NGOs and public institutions can collaborate outside these organisations. According to Polish legislation, the forms of collaboration between these entities are regulated by, among others, the Act of law of 24 April 2003 on Public Benefit and Volunteer Work, Art. 5 , item 1. However, we should bear in mind that not all these forms are in agreement with the NPG concept. According to the legislation, collaboration between NGOs and public institutions can refer to commissioning public works to NGOs, the mutual passage of information concerning planned courses of action, the consultation of projects of normative acts, the creation of common advisory and initiative panels, the execution of local initiatives based on agreements and collaboration-based partnership agreements. Therefore, when analysing the forms of collaboration described in the legislation, we can see that collaboration is understood, in a broad sense, as (1) the mutual passage of information, (2) the execution of tasks commissioned to NGOs by rural gmina offices and (3) the co-construction and co-production of services possible according to partnership agreements. Cooperation between NGOs and the public sector is also possible as part of

\footnotetext{
2 The LEADER approach is a method of stimulating rural areas' development in the EU, which has been implemented since 1991. Poland introduced this after its accession into the EU in 2004. Since 2014, this method of development has included urban areas, as part of community-led local development, which relates to the principles of the LEADER approach. One such rule was partnership between the public sector (which includes rural gmina offices and local authorities), the social sector (which includes NGOs) and the economic sector (local entrepreneurs). The cooperation of representatives of three sectors was to take place as part of newly created organisations called local action groups, enabling all sides to co-construct and coproduce social services.
} 
projects financed by the European Social Fund or as a part of local initiatives (Kotarba 2015, p. 65). It is not always formal. The emergence of formal partnerships (as is the case in other countries) is at times preceded by the informal cooperation of interested entities (see van Tulder et al. 2016, p. 2), which representatives define as a partnership (Kotarba 2015, p. 64).

The terms co-construction and co-production are understood differently (Pestoff 2012, p. 1105-1107). Voorberg et al. (2015, p. 1347) state that in the literature the concepts of co-creation and co-production were often seen as interchangeable. There is empirically no striking difference between both concepts, and within bodies of knowledge different meanings are given to both concepts'. In reference to the NPG concept, we focus on the phenomenon of collaboration between rural gmina-based NGOs and rural gmina offices. This collaboration is defined as a form of interaction, which implies the coconstruction and co-production of social services as a part of partnership agreements. Partnership agreements can be formal and written; however, in rural areas, informal contacts between the leaders of local authorities and the leaders of NGOs, and the ensuing practices of these contacts, are often more important. In other words, the fact that institutions do not base cooperation on written legal contracts, in which the rights and obligations of both sides are determined in accordance with the principles of partnership, does not mean that these institutions do not collaborate in accordance with these principles. In reference to the approach suggested by Kotarba (2015, p. 65) (who analysed the theoretical possibilities of cross-sectoral cooperation in Poland), co-construction is defined as common, i.e. assuming the participation of two sides, planning and creating of social services, whereas co-production means providing that service, also assuming the participation of both sides.

Relatively few empirical studies on cooperation between NGOs and public institutions (taking into consideration the co-construction and co-production of social services) have been conducted in post-socialist states (Mikušova Meričkova et al. 2015), particularly in rural areas. Polish researchers focus primarily on the idea of cooperation itself. Firstly, they report on its potential advantages, taking into account the significance of NGOs for activities directed at resolving social problems, satisfying social needs, representing the interests of disadvantaged groups, maintaining close contact with residents of various territorial units and their propensity to implement innovative actions, which exceeds that of the public sector (Zajda 2017). Secondly, the researchers emphasise the difficulties of cross-sectoral cooperation, its occasional apparentness and its social impact (Pawlowska and Gasior-Niemiec 2015). Therefore, when designing studies in Polish rural areas, we bore in mind that formal written partnership agreements can be differently implemented in practice. Some agreements can imply the co-construction and coproduction of social services, which do not occur in reality. That is because NGOs can give into pressure exerted by local authorities and state in their documents that there was cooperation in the scope of co-construction and co-production of social services, when in fact the NGOs implemented the projects by themselves. We also took into account that an NGO, which is formally responsible only for providing a social service, in accordance with guidelines issued by the gmina office, may actually produce and provide the service along with this office, which is not reflected in formal documentation. Taking all of this into consideration, our own research was based on the opinions of NGO leaders, which may reflect reality to a greater extent than existing documents.

\section{Traits of NGO Leaders and the Potential of NGOs to Enter into Collaboration}

Few studies describing leadership traits that can influence cooperation between NGOs and other entities can be found in the source literature. Among these traits, gender has been mentioned. After conducting a review of the relevant literature, AbouAssi et al. (2016) indicated that according to numerous studies, organisations led by women collaborate more often with other entities than those led by men. Referring to studies by Foster and Meinhard (2002) on the predispositions of organisations to collaborate, they emphasised that 'NGOs managed by women may be more likely to enter into collaborative relationships than organisations run by men. The psychosocial development of women is more compatible with being a successful collaborator; women are more communal and consensus builders and prefer participatory and collective approaches to solving problems more than men' (AbouAssi et al. 2016, p. 445).

The second trait of NGO leaders that can facilitate collaboration between their organisations and other entities is openness to experience-a trait listed in the five-factor model of personality (together with extraversion, agreeableness, conscientiousness and neuroticism) (McCrae and Costa 1987, 2008; McCrae and John 1992). The Big Five model is often used as a basis for measurement of personality predictors of the effectiveness of actions taken by various organisations (i.e. not only NGOs), including their potential to collaborate with other entities (Hassan et al. 2017, p. 75; Soomro et al. 2016).

The source literature more frequently indicates traits that facilitate leadership of organisations and that can influence their activities. These traits include interpersonal 
skills (King 2004, p. 478), such as social skills (AbouAssi et al. 2016, p. 437), which are also described as social competences (Riggio et al. 1990, p. 799). These traits can be considered especially useful for leaders of various organisations due to the need to clearly communicate one's position and display assertiveness in situations in which matters of interest are involved in a way that minimises the social costs of oppositional reactions.

Stump and colleagues $(2010$, p. 23) stated that social competences are a 'little understood construct that nonetheless remains a hallmark of positive, healthy functioning across the life span'. There are a few definitions of social competences. However, what we know for certain is that an individual can possess various social competences and, as Riggio (1986, p. 650), an expert on the subject, pointed out: 'The relation between any single social skill dimension and social effectiveness (i.e. positive or desirable social outcomes) may not always be linear. Possessing too much of any one of the basic components of social skill, in relation to other key social skill components, may be dysfunctional. In another study, the author highlighted that such competences (e.g. emotional expressivity, emotional sensitivity, emotional control, social expressivity, social sensitivity, social control; Riggio and Taylor 2000, p. 651) 'indeed consist of an ability, or group of abilities, that facilitate the initiation, development and maintenance of human relationships' (Riggio et al. 1990, p. 799).

People who display high social competences find it easier to enter into various social interactions. Riggio's studies indicate that various social competences correlate to various degrees of an internal locus of control. An increase in a given competence does not always indicate an increase in one's internal locus of control (Riggio et al. 1990 , p. 800).

In the context of the social competences of NGO leaders, we should draw attention to the issue of reacting to social influence or resistance to social impact.

The notion of resistance has a broad range of meanings, indicating such concepts as reactance, negativity, rebellion and disobedience. However, in the context of findings by various authors (Apter 1982; Brehm 1966; Brehm and Brehm 1981; McDermott 2001), we can perceive resistance as both a function of interpreting social situations and a subjective inner experience. In this sense, resistance constitutes a readiness to resist unwanted influence and social restrictions (cf. McDermott 2001; Knowles and Riner 2007; Pasikowski 2016a). This readiness should be understood as a conscious mental attitude of the subject, who is capable of immediate reaction, which is directed at limiting the influence of an external impact which he/she perceives as unwanted and opposed to himself/herself (cf. Apter 1982, 2001a, b; McDermott 2001). This reaction can assume various forms (Bukobza 2009; Dowd et al. 1991;
McDermott 1988; Stenner and Marshal 1995) and can be characterised using two more general properties (Ames 2007; Ames and Flynn 2007; Deluty 1979). The first property is an activity, i.e. the degree to which one directly enforces or defends one's position, which can be described using two poles: passive to active (cf. Aggleton and Whitty 1985; Fernandes 1988; Goffman 1961; Knowles and Riner 2007; Thomas et al. 2001; Zimbardo 2008). The second property is acceptance, which is described as the strength with which a person acknowledges the source of the pressures and restrictions he/she experiences, with the intent to build or sustain social relations (Pasikowski 2016a, b). Doing so would consist of becoming agreeable (conforming) to the opinions and convictions of others and in presenting oneself as attractive in the eyes of others (cf. Jones and Wortman 1973; DeLamater and Myers 2011). In the case of both behaviours, the aim is to obtain access to certain goods and benefits or to preserve the existing state of affairs. Such behaviours are treated as being within the bounds of interpersonal persuasion techniques (Blickle 2003; Bohra and Pandey 1984; Ellis et al. 2002; Gordon 1996) and are interpreted in terms of reducing the degree of dependence on others (Baumeister 1982).

After combining these two properties, i.e. activity and acceptance, in a two-dimensional system, four forms of resistance can be identified: the expression of negative emotions and aggression, passiveness, apparent adaptation and the assertive expression of one's position (Pasikowski 2016a, b), all of which can prove useful in building a profile of NGO leaders, i.e. people who enter into numerous interpersonal and group relations, in the course of which matters of importance from the point of view of the role of such a leader are negotiated.

Another trait indicated in the source literature in the context of fulfilling the role of NGO leaders, and in the context of their activity, is education. Based on representative studies conducted in Poland, Sułek (2013, p. 290) noted: 'Educational attainment, especially in the case of higher education, not only contributes to membership in voluntary organisations_-persons with higher education are also more likely to work in such organisations. As a result, persons from the upper social strata, and in particular persons with higher education, are several times more likely to be elected and serve in civil organisations'.

The theoretical findings listed above justify the search for a set of specific traits of NGO leaders that can influence the establishment of collaboration between their organisations and other organisations and institutions, including public institutions. Some of these traits can be characterised as purely psychological variables, while the others pertain to sex and education. Even though the age variable is not emphasised in the source literature, it was included in our analysis. The social perception of a leader's age can 
have significance in terms of such traits as responsibility and credibility (Spisak et al. 2014; Van Vugt and Grabo 2015), which can in turn influence collaboration with representatives of public institutions in accordance with the NPG model. In the light of the above findings, we formulated two basic questions:

(1) Do psychological traits of rural NGO leaders, such as social competences, readiness to resist unwanted social influence, locus of control and openness to experience, determine the establishment of collaboration between these organisations with rural gmina offices?

(2) Does the set of traits of these leaders that determines the establishment of collaboration between rural NGOs and rural gmina offices include sex, age and education?

We sought answers to these questions by building a logistic regression model, based on data collected in 2017.

\section{Method}

\section{Participants}

Participants in this study comprised 104 leaders of NGOs. The results from 13 respondents were rejected from the analysis, five due to insufficient data and eight because of strong deviations from the study results. The final analysis included data from 91 respondents: 62 women and 29 men. The average age of the respondents was 53 (mean $=52.68$, median $=52$, standard deviation $=12.54$, asymmetry $=$ 0.16 , kurtosis $=-0.37, \min =27, \max =83$ ), and its empirical distribution did not deviate significantly from the normal distribution (Shapiro-Wilk $=0.89, p=0.5743$ ). The distribution of education in the sample was as follows: 13 people with vocational education, 32 people with secondary education, five people with first-degree university education and 41 people with second-degree university education.

\section{Tools}

Five independent tools were used in the study: the interview questionnaire, the PROKOS (Eng. Social Competences Profile) questionnaire, the Człowiek w Pracy (Eng. Person at Work) (CP) questionnaire, the Questionnaire of Readiness to Resist and the Openness to Experience (O) scale from the NEO-FFI personality inventory. The reported validity of the tools was established in separate investigations by their authors. Information concerning each tool is presented below.
The interview questionnaire included the following question: Did the NGO under your management collaborate with a rural gmina office in the year 2016 as part of a partnership agreement, i.e. cooperate with a gmina office in the construction and production of specific social services? $?^{3}$ The questionnaire was also used to ask the respondents about their age, sex and education.

The second tool was the PROKOS ${ }^{4}$ questionnaire, created by Matczak and Martowska (2013), which is used to study social competence profiles. The PROKOS is usually applied in studies conducted in sociocultural contexts in Poland. There is no English version of the questionnaire. Conversely, Polish adaptations of tools developed by foreign authors, which could have been used instead of the PROKOS, were also unavailable. The PROKOS questionnaire allows for the measurement of social competences in five dimensions, which correspond to the following scales extracted by the authors through validity studies:

(1) assertive competences $\left(\mathrm{A}^{5}-14\right.$ items) - expressed by the ability to exert influence on others while respecting the standard of socially acceptable behaviours and preserving balance between soliciting for the realisation of one's needs and aims and the social approval of one's conduct.

(2) cooperative competences (K-16 items) - characterise people who can collaborate with others in an effective and harmonious manner. These competences are connected with a tendency to take helpful actions and with a conviction about one's effectiveness in this scope.

(3) sociable competences (T-11 items) — connected with initiating and maintaining informal contacts and with coping in situations of social exposure.

(4) community competences ( $\mathrm{S}-6$ items) - the ability to initiate and implement social goals and to involve other people in activities which serve those goals. These competences are particularly necessary for people working in public benefit organisations.

\footnotetext{
3 The questionnaire was accompanied by instructions for the interviewers, which included definitions (mentioned earlier in this article) of the co-construction and co-production of social services, as well as examples of such cooperation, as part of formal or informal partnership agreements. The interviewer informed the respondent how to define these terms and provided examples of such cooperation (if necessary).

4 A licence for the use of the PROKOS and Człowiek w Pracy questionnaires was purchased from the Psychological Test Laboratory of the Polish Psychological Association.

5 The symbols used to signify the scales of the PROKOS and Człowiek w Pracy questionnaires were derived from the Polish names of these scales. We left the original symbols because of the lack of English-language versions of these tools and because the authors have thus far not publicised names for these scales other than the original ones.
} 
(5) social resourcefulness (Z-13 items)—expressed through the ability to obtain goods and evoke expected behaviours in other people.

The authors determined the scales' internal coherence to be $0.82-0.89$ (Cronbach's $\alpha$ ) and that their structural, convergent and differential validity was satisfactory. Convergent validity was assessed in the course of studying correlational relationships with numerous tools measuring similar constructs with regard to social competences. Differential validity was assessed through correlations with tools measuring opposing constructs.

Another tool used in the study was the Człowiek w Pracy questionnaire by Matczak et al. (2009). The questionnaire is designed to measure the locus of control with regard to the conditions of one's occupation-in this case, activity as part of an NGO. The questionnaire is usually applied in studies conducted in sociocultural contexts in Poland. There is no English version of the questionnaire. Polish adaptations of tools by foreign authors, which could have been used instead of the questionnaire, are also unavailable in Poland. In the course of validation study, the authors discovered that the questionnaire possesses a twofactor structure. The first factor is called the Sense of Control Locus (PUK-41 items), while the second, which encompasses positions of control, is called the Control Scale (19 items). Further studies allowed the authors to highlight two additional factors within the PUK scale. These factors were given the following names:

(1) control ideology (ik-27 items) - used to measure generalised perceptions of people's influence on the course of their activities, aims and actions.

(2) personal control (ko-14 items) - used to measure convictions about the possibility of controlling one's fate and deciding one's activities.

The results of these scales are used in the diagnosis of the locus of control. ${ }^{6}$ The positions of both scales concern convictions and perceptions with regard to the context of work. Internal coherence of the control ideology and personal control scales was tested, taking into account separate age groups. The average Cronbach's $\alpha$ was 0.83 for $\mathrm{CP}(\mathrm{ko})$ and 0.88 for $\mathrm{CP}(\mathrm{ik})$. The assessments of convergent and differential validity conducted by the authors of the tool demonstrated that it provided credible measurements.

Another tool implemented in the study was the Questionnaire of Readiness to Resist (QRR) (Pasikowski 2016a, b), which is used to measure resistance in situations of interpersonal influence. The questionnaire is

\footnotetext{
${ }^{6}$ It is especially important to highlight that the personal control $(\mathrm{CP}(\mathrm{ko}))$ and control ideology $(\mathrm{CP}(\mathrm{ik}))$ scales provide reverse results. This means that if the result in a given scale is high, then the trait measured using this scale is low in intensity.
}

characterised by a four-factor structure. The positions of each factor create separate scales, which are described as follows:

(1) retaliation (Rt-6 items) - used to measure readiness to the targeted expression of anger and dislike and taking action against or to the detriment of those from whom one experiences pressure.

(2) assertive confrontation (Ac-6 items) - used to measure readiness to openly communicate one's lack of consent to unwanted social impact, supported by the search for arguments that could change the situation while respecting the rights of others.

(3) opportunism (Op-5 items) - readiness to instrumentally create an impression of submissiveness that would enable one to secretly fulfil his/her goals or minimise potential losses connected with open objection.

(4) inertia (In-3 items) — used to measure readiness to restrict contact, withdraw, avoid, refuse or reject actions, possibly connected with hostility towards people trying to exert influence or towards pressure.

Validity assessment showed that the convergent and differential validity of the scales, as well as their homogeneity, which had a Cronbach's $\alpha$ of $0.71-0.83$, were satisfactory.

The final tool used in the study was the Openness to Experience scale $(\mathrm{O})$ from the Polish version of the NEOFFI Personality Inventory (Zawadzki et al. 1997), which is used to measure the personality trait which expresses cognitive interest, tolerance towards novelty and the tendency to seek and assign positive value to novelty. In the Polish validity assessment, the scale had similar validity to that of the original studies, with a homogeneity value of Cronbach's $\alpha 0.68$.

\section{Procedure}

Empirical studies were conducted between January and April 2017 in the Lodz voivodeship, which is in central Poland. It belongs to a group of five Polish voivodeships (of which there are 16 in total) with the lowest number of associations and foundations per 10 thousand people (Adamiak et al. 2016, pp. 9, 29).

The study covered NGOs with headquarters in all 29 rural gminas situated around the three largest cities of the voivodeship (Lodz, Piotrkow Trybunalski, Skierniewice). All the rural gminas in which the study was conducted were supported by local action groups, which means that the idea of collaboration between NGOs and public institutions, such as rural gmina offices, was somewhat implemented in their areas. Therefore, on the one hand, the studies were conducted in the voivodeship characterised by 
low citizen involvement in the form of formalised NGOs; and, on the other, the rural gminas where these organisations were situated were receiving support from local action groups. A small number of NGOs could paradoxically help such organisations in their collaboration with rural gmina offices. The leaders of these NGOs could, relatively easily, establish contacts with representatives of rural gmina offices and seek their cooperation, which would consist of the co-construction and co-production of social services. $^{7}$

The study participants were leaders of NGOs (associations, unions of associations and foundations) situated in these rural gminas. The leaders were identified by members of the organisations during telephone or email contact made by researchers. In all organisations, only one leader was selected. The study did not include sports clubs, adhering to information (mentioned earlier in the article) found in the source literature.

Based on the database of NGOs bought from the Central Statistical Office in Poland, the researchers determined the number of organisations in the area of the selected rural communes to be 397 . Bearing in mind the problems with updating the Central Statistical Office database described in the source literature (Działek 2014; Zajda 2017), the purchased data were verified. During the 4 weeks prior to the beginning of the study, at least three attempts were made to contact representatives of each organisation by phone or email (at three different times during the day, including the evening). The verified sampling frame from which the organisations were selected by means of a lottery consisted of 142 subjects. Based on this number $(N)$, the minimal size of the sample for dependent individual sampling was determined, with an estimated confidence level (CL) of 0.95 , an estimated value ( $f$ ) of 0.5 for an unknown fraction size and a 5\% estimation error $(e)$. The sample size was $n_{\min }=103.87$. Thus, 104 organisations were selected. The sample is representative of the studied communes. Unfortunately, 13 cases were excluded from the analysis due to insufficient data, and eight because of outlier results. Admittedly, the reduction in sample size decreases the credibility of the inference, with the established criteria underlying the necessary sample size $(N=142, \mathrm{CL}=0.95$, $f=0.5, e=0.05$ ). However, data loss will seem more acceptable and under control, when it is noted that the number 91 corresponds with the situation in which the estimation error $(e)$ is $6.2 \%$, thus being just over $1 \%$ higher than initially expected. With an estimation error of $6.5 \%$, the minimal sample size would be 88 units.

\footnotetext{
7 Such a context of rural gminas made the study more interesting; however, its aim was not to compare the situation in these areas with others, e.g. with a greater number of NGOs, but to highlight that even in such areas (with a deficit in NGOs) one could expect cooperation between non-governmental organisations and public institutions.
}

After contacting the leaders of the selected organisations, we asked each one to fill out a set of psychological questionnaires in the presence of an interviewer. Moreover, each respondent was individually asked questions from the interview questionnaire prepared by the researchers. The study was carried out in accordance with a correlative scheme comprising a single-point measurement of a set of traits predicted in the theoretical model. Responses to requests for cooperation and the respondents' sex were coded in binary. In the case of cooperation, the value attributed was ' 1 '; otherwise, the value was ' 0 '. Men were attributed ' 0 ', and women were attributed ' 1 '. The variants of the ordinal variable 'education' were attributed the following value levels: vocational education-1, secondary education-2, first-degree university education-3, second-degree university education-4. The cumulative values corresponding with the individual scales of the other questionnaires were treated as continuous variables.

The analysis consisted of two stages. In the first stage, we used measures of statistical description to characterise the traits of NGO leaders that were included in the studies. In the second stage, we used logistic regression analysis to assess the role of these traits in determining the chances for collaboration between NGOs and rural gmina offices.

Logistic regression is recommended when the dependent variable has a dichotomous form, as well as when the aim of the data analysis is to test the models of relationships between the dependent variable and variables treated as its determinants (Hosmer et al. 2013; Kleinbaum and Klein 2010; O'Connell 2006; Osborne 2015). The variants of the dependent variable in the analysis were success and failure. Success signifies fulfilling a given criterion, e.g. the presence of a given phenomenon or value, while failure means that the criterion was not fulfilled. This method allowed us to estimate the natural logarithm of success probability (more generally, the chances of success taking place), not the intensity of the dependent variable, as in the case of linear regression. Additionally, it offered us the opportunity to use the term chances of success (to this end, we calculated the odds ratio), which differs from probability in that it assumes values in the range $(0,+\infty)$. To describe the model of logistic regression and assess the chances of success, we used the following equation:

Formula 1 Equation of logistic regression

$P(X)=\frac{e^{\beta_{0}+\sum_{i=1}^{k} \beta_{i} x_{i}}}{1-e^{\beta_{0}+\sum_{i=1}^{k} \beta_{i} x_{i}}}$

where $\beta_{0}$ is the constant, $\beta_{i}$ are direction coefficients for the $x_{i}$ variables in the model, and $e$ is Euler's number, i.e. the basis of the natural logarithm, which in this equation constitutes a constant with an approximate value of 2.718 . $P(X)$ assumes values in the range of $(0,1)$. 
In the presented study, the dependent variable constituted collaboration between NGOs and rural gmina offices, as declared by NGO leaders. Statistical inference was conducted on the assumed level of statistical significance $\alpha=0.05$.

\section{Results}

Out of 91 leaders of the studied NGOs, 68 (75\%) indicated that their organisations collaborated with rural gmina offices on both the co-construction and co-production of social services in 2016.

The first stage of data analysis was a statistical review of the descriptive measurement results of traits of the studied NGO leaders, i.e. their social competences, readiness to resist, locus of control and openness to experience (Table 1). The characteristics of the age, sex and education of the leaders were provided in an earlier section of this article.

When we refer the mean values of the sample measurement to reference values in the population, we can see a rather high intensity of social competences $(\mathrm{T})$, openness (O), assertive confrontation (Ac) and inertia (In), as well as a moderate intensity of retaliation $(\mathrm{Rt})$, opportunism (Op), control ideology $(\mathrm{CP}(\mathrm{ik}))$ and personal control $(\mathrm{CP}(\mathrm{ko}))$.

The second stage of data analysis consisted of a logistic regression analysis, in accordance with the step backwards pattern with regard to the variables in the model with a statistically insignificant directional coefficient. At the point of departure, we took into consideration all independent variables, i.e. measurement results in the $\mathrm{QRR}$, PROKOS and CP subscales, as well as data concerning the sex, education and age of the respondents. Then, in the case of each successive model, we removed the variable with the lowest value according to the chi $^{2}$ Wald test (statistically insignificant) from among those variables with statistically insignificant directional coefficients. The value of this test constituted the final elimination criterion, preceded by an earlier evaluation of the statistical likelihood ratio (chi ${ }_{\mathrm{LR}}^{2}$-likelihood ratio), which refers to the difference between the $\mathrm{chi}^{2}$ coefficients of fitting the compared models. In Table 2, we presented the parameters of fitting the created models. The goodness-of-fit estimation was carried out using the quasi-Newton method.

In all models, the iterative estimation function reached convergence (model fit to empirical data), which means that the results of the analysis were not burdened with distortions caused by insufficient fitting. The data presented in Table 2 indicate that each of these models differs significantly from the model that includes only the constant $\left(\mathrm{chi}^{2}\right)$. It is therefore justified to take it into account in predicting collaboration between NGOs managed by their leaders and rural gmina offices (dependent variable). The predicted significance of the models proved to be justified, as we can see by the coefficients of determination (pseudo $R^{2}$ ), which show the extent to which the probability of success for a given dependent variable is explained by the regression model. In the model that includes all the variables, the chances of predicting collaboration were $62 \%$ and decreased with the elimination of successive variables; however, it did not fall below $44 \%$ in the final model, in which the number of predictors was reduced to four. It should be added that apart from the final model (number 12), model number 8 also drew our attention with its significantly higher fit than previous models (the $p$ value in the final column).
Table 1 Descriptive statistics Source: Own studies

\begin{tabular}{llllcrrr}
\hline Variable & Mean ar. & Median & SD & Asymmetry & Kurtosis & Min & Max \\
\hline Rt & 12.63 & 12.00 & 6.00 & 1.31 & 2.58 & 6 & 37 \\
Ac & 34.07 & 35.00 & 6.24 & -1.16 & 2.02 & 12 & 42 \\
Op & 14.73 & 14.00 & 5.95 & 0.72 & 0.37 & 5 & 35 \\
In & 10.93 & 11.00 & 4.82 & 0.08 & -0.72 & 3 & 21 \\
A & 42.78 & 43.00 & 6.29 & -0.38 & -0.22 & 25 & 56 \\
K & 54.64 & 55.00 & 6.67 & -0.88 & 0.98 & 32 & 64 \\
T & 35.43 & 36.00 & 6.38 & -0.60 & -0.26 & 18 & 44 \\
Z & 42.13 & 43.00 & 6.81 & -0.98 & 1.92 & 15 & 52 \\
S & 18.21 & 19.00 & 3.21 & -0.28 & -0.96 & 11 & 24 \\
O & 29.03 & 28.80 & 7.03 & 0.18 & -0.46 & 12 & 47 \\
CP (ik) & 56.86 & 57.00 & 6.96 & 0.25 & 0.73 & 39 & 80 \\
CP (ko) & 25.93 & 26.00 & 5.19 & 0.17 & 0.35 & 14 & 42 \\
\hline
\end{tabular}

$R t$ retaliation, $A c$ assertive confrontation, $O p$ opportunism, In inertia, $A$ assertive competences, $K$ cooperative competences, $T$ sociable competences, $Z$ social resourcefulness, $S$ community competences, $O$ openness to experience, $C P(i k)$ control ideology, $C P(k o)$ personal control 
Table 2 Fitting logistic regression models. Source: Own studies

\begin{tabular}{|c|c|c|c|c|c|c|c|c|}
\hline \multirow[t]{2}{*}{ Model number } & \multicolumn{3}{|c|}{ Fitting of model } & \multicolumn{2}{|l|}{ Pseudo $R^{2}$} & \multicolumn{3}{|c|}{ Difference between neighbouring models } \\
\hline & $\operatorname{chi}^{2}$ & $d f$ & $p$ & Cox and Snell & Negerkelke & $\operatorname{chi}_{\mathrm{LR}}^{2}$ & $d f$ & $p$ \\
\hline 1 & 50.17 & 15 & 0.0000 & 0.42 & 0.62 & & & \\
\hline 2 & 50.12 & 14 & 0.0000 & 0.42 & 0.62 & 0.05 & 1 & 0.8235 \\
\hline 3 & 49.99 & 13 & 0.0000 & 0.42 & 0.62 & 0.12 & 1 & 0.7238 \\
\hline 4 & 49.72 & 12 & 0.0000 & 0.42 & 0.61 & 0.27 & 1 & 0.6003 \\
\hline 5 & 48.92 & 11 & 0.0000 & 0.42 & 0.61 & 0.8 & 1 & 0.3705 \\
\hline 6 & 46.93 & 10 & 0.0000 & 0.40 & 0.59 & 1.99 & 1 & 0.1588 \\
\hline 7 & 44.89 & 9 & 0.0000 & 0.39 & 0.57 & 2.04 & 1 & 0.1534 \\
\hline 8 & 40.99 & 8 & 0.0000 & 0.36 & 0.53 & 3.91 & 1 & 0.0481 \\
\hline 9 & 38.59 & 7 & 0.0000 & 0.35 & 0.50 & 2.4 & 1 & 0.1215 \\
\hline 10 & 37.17 & 6 & 0.0000 & 0.33 & 0.49 & 1.42 & 1 & 0.2331 \\
\hline 11 & 35.14 & 5 & 0.0000 & 0.32 & 0.47 & 2.02 & 1 & 0.1550 \\
\hline 12 & 32.93 & 4 & 0.0000 & 0.30 & 0.44 & 2.21 & 1 & 0.1368 \\
\hline
\end{tabular}

A presentation of the predictors was carried out based on data from model 12 with reference to the results in models 8,7 and 3. This decision was supported by the number of statistically significant predictors in these models, as well as by the similarity in the goodness of fit to the data and the size of chance of predicting the independent variable.

A comparison of the model fit coefficients of models 12 and 8 (the first model that differed significantly from the previous ones: $\mathrm{chi}^{2}=3.91, d f=1, p=0.0481$ ) showed their mutual similarities $\left(\mathrm{chi}^{2}=8.06, d f=4, p=0.0895\right)$ in spite of difference in the number of parameters (which equalled 4). Thus, the differences between these models consisted mostly in the number of significant predictors and their credibility. On the other hand, models 12 and 7 (the model directly preceding the first model, which differed significantly from the previous ones) showed significant differences in goodness of fit $\left(\mathrm{chi}^{2}=11.96, d f=5\right.$, $p=0.0353$ ). This result is in accordance with predictions. A similar result was obtained in the comparison between models 12 and $3\left(\mathrm{chi}^{2}=17.06, d f=9, p=0.0478\right)$, the latter of which possessed the highest number of statistically significant parameters, i.e. for the Rt, In, A, Z, CP (ik), CP (ko), age and education variables. However, in this comparison, attention should be drawn to the value $p$, which indicates that the probability of not rejecting the null hypothesis (which assumes similarity between both models) did not decrease significantly.

Although the final form of the model is of key significance, referring to the results of the comparison with rejected models allows us to consider the initial theoretical assumptions concerning the set of predictors to be justified. The presentation of the components of the final model can be found in Table 3 .
The data analysis also included the possibility of first-, second- and third-order interactions between predictors present in interaction model 12. However, none of them were statistically significant, which means that the effect of the predictor's impact on the explained variable was additive in nature. The results are shown in Table 4.

The sign of particular directional coefficients calculated for the variables in model 12 (Table 3) indicates that the probability of collaboration between NGOs (managed by their leaders) and rural gmina offices increases with the increase in the leaders' level of education and the results of the $\mathrm{S}$ and $\mathrm{CP}(\mathrm{ko})$ scales and the decrease in the results of the $\mathrm{CP}(\mathrm{ik})$ scale. $^{8}$ In contrast, the odds ratio (OR) coefficients indicate that the probability of establishing collaboration with rural gmina offices increases nearly fourfold when the level of education is increased, increases by nearly $50 \%$ alongside an increase in the results of the $\mathrm{S}$ scale and increases by $30 \%$ alongside an increase in the results of the $\mathrm{CP}(\mathrm{ko})$ scale, by 1 point. A 1-point increase in the $\mathrm{CP}(\mathrm{ik})$ scale results in a $23 \%(\mathrm{OR}=0.77)$ decrease in the probability of cooperation with rural gmina offices. After substituting the values of directional coefficients into formula 1, we obtained the following model of logistic regression:

Formula 2 Equation of logistic regression for cooperation variable

$P($ cooperation $)=\frac{e^{-1.74+0.43 S-0.27 \mathrm{CP}(\mathrm{ik})+0.28 \mathrm{CP}(\mathrm{ko})+1.26 \mathrm{EDU}}}{1-e^{-1.74+0.43 S-0.27 \mathrm{CP}(\mathrm{ik})+0.28 \mathrm{CP}(\mathrm{ko})+1.26 \mathrm{EDU}}}$

\footnotetext{
$\overline{8}$ Once again, we point out that the $\mathrm{CP}(\mathrm{ik})$ and $\mathrm{CP}(\mathrm{ko})$ scales provide inverse results. This means that if the result in a given scale is high, then the trait which it measures is low in intensity.
} 
Table 3 Logistic regression model no. 12 for the cooperation with rural gmina offices. Source: Own studies
Table 4 Interactions in logistic regression model no. 12 . Source: Own studies

\begin{tabular}{lrlrlllc}
\hline Parameter & \multicolumn{1}{c}{ Coeff. } & SE & \multicolumn{1}{c}{$t(86)$} & \multicolumn{1}{l}{$p$} & OR & $-95 \%$ CI & $+95 \%$ CI \\
\hline Constant & -1.74 & 3.03 & -0.57 & 0.5682 & 0.18 & 0.00 & 72.84 \\
S & 0.43 & 0.13 & 3.26 & 0.0016 & 1.53 & 1.18 & 1.98 \\
CP (ik) & -0.27 & 0.08 & -3.21 & 0.0019 & 0.77 & 0.65 & 0.90 \\
CP (ko) & 0.28 & 0.11 & 2.42 & 0.0178 & 1.32 & 1.05 & 1.65 \\
EDU & 1.26 & 0.35 & 3.59 & 0.0005 & 3.51 & 1.75 & 7.03 \\
\hline
\end{tabular}

\begin{tabular}{lcccccc}
\hline Parameter & Coeff. & SE & Wald & $d f$ & $p$ & OR \\
\hline $\mathrm{CP}(\mathrm{ko}) * \mathrm{CP}(\mathrm{ik})$ & 0.000 & 0005 & 0.01 & 1 & 0.9330 & 1.00 \\
$\mathrm{CP}(\mathrm{ko}) * \mathrm{~S}$ & -0.02 & 0.017 & 1.45 & 1 & 0.2280 & 0.98 \\
$\mathrm{CP}(\mathrm{ik}) * \mathrm{~S}$ & -0.02 & 0.015 & 1.69 & 1 & 0.1930 & 0.98 \\
$\mathrm{CP}(\mathrm{ko}) * \mathrm{EDU}$ & 0.09 & 0.06 & 2.27 & 1 & 0.1320 & 1.10 \\
$\mathrm{CP}(\mathrm{ik}) * \mathrm{EDU}$ & 0.08 & 0.05 & 3.39 & 1 & 0.0650 & 1.09 \\
$\mathrm{~S}$ EDU & 0.04 & 0.09 & 0.22 & 1 & 0.6350 & 1.04 \\
$\mathrm{CP}(\mathrm{ko}) * \mathrm{CP}(\mathrm{ik}) * \mathrm{~S}$ & 0.09 & 0.06 & 2.27 & 1 & 0.1320 & 1.10 \\
$\mathrm{CP}(\mathrm{ko}) * \mathrm{CP}(\mathrm{ik}) * \mathrm{EDU}$ & 0.08 & 0.05 & 3.39 & 1 & 0.0650 & 1.09 \\
$\mathrm{CP}(\mathrm{ko}) * \mathrm{~S}$ EDU & 0.003 & 0.003 & 1.09 & 1 & 0.2970 & 1.00 \\
$\mathrm{CP}(\mathrm{ik}) * \mathrm{~S} * \mathrm{EDU}$ & 0.001 & 0.001 & 1.37 & 1 & 0.2410 & 1.00 \\
$\mathrm{CP}(\mathrm{ko}) * \mathrm{CP}(\mathrm{ik}) * \mathrm{~S} * \mathrm{EDU}$ & 0.000 & 0.000 & 1.34 & 1 & 0.2480 & 1.00 \\
\hline
\end{tabular}

When we substitute the concrete values obtained through individual measurements of the variables for the variable symbols, it is possible to calculate the probability of an NGO, managed by a given person, to enter into cooperation with a rural gmina office.

We need to emphasise that the presented model gives us a $44 \%$ chance of predicting the odds of cooperation (corrected pseudo $R^{2}$ ). This is a significant effect, bearing in mind the complexity of the conditions for establishing cooperation between NGOs and rural gmina offices, which is connected with the existence of many possible determinants of such cooperation. The obtained results allow us to recognise some of them, as well as to assess their degree of importance.

\section{Conclusions}

The results of the conducted analysis allow us to provide a positive answer to the questions raised in the introduction; however, this answer needs to be elaborated further.

The overall good fit of the models to the data confirms the validity of the theoretical assumptions, which means that all the models tested during these analyses can be considered valuable in the scope of predicting the odds of cooperation between rural NGOs from the selected region of central Poland and rural gmina offices (in accordance with the NPG concept). However, the key role in determining cooperation with rural gmina offices, consisting of the co-construction and co-production of social services, is played by education, social competences and locus of control. Among this set of traits, we need to highlight the education of NGO leaders, the increasing level of which was the most decisive for establishing cooperation between these organisations and rural gmina offices. This allows us to formulate a practical conclusion concerning the need to invest in raising the level of education of citizens in rural areas who are active in NGOs.

The significance of social competences for such cooperation is in accordance with expectations that NGO leaders (who become involved in cooperation with rural gmina offices) are characterised by the readiness to take pro-social initiatives. Thus, social competences can and should be the subject of education in a post-socialist country in which individualist values predominate over collectivist values (Łabędź 2015, p. 76). In other words, people who are active in NGOs (especially their leaders) are characterised by a higher level of social competences in relation to the overall population; however, their motivations for involvement can be questioned by those with whom they are in contact (including rural gmina offices), which could, in turn, threaten to reduce their social activity. The education of these leaders, which highlights the significance of social competences in the context of their activities in rural areas of a post-socialist state, may ultimately be helpful in developing, shaping and raising their competences. 
The final, crucial trait which determines the cooperation between NGOs and rural gmina offices is the locus of control. The data analysis reveals that the odds of such cooperation increase alongside an increase in conviction on the part of the leaders of such organisations that current and past experiences connected with the context of work and activity, as part of these organisations, depend on factors which are beyond their individual influence; conversely, the odds of cooperation decrease with the conviction that, in general, people in work environments have little influence over the course of their professional careers. The apparent contradiction should be viewed as a compromise between the conviction of maximised individual control over one's fate on the one hand, and the conviction of minimised influence over professional careers on the other. However, we need to remember that the intensity of both characteristics, as measured by the personal control and control ideology scales, does not deviate from the level found in the general population, on which the standardisation of the $\mathrm{CP}$ scale was performed. In the context of possible actions in support of leaders' individual potential, which determines cooperation between NGOs and rural gmina offices, it seems worthwhile to foster balanced convictions about the potential to influence the environment and take effective action, while also shaping beliefs about the importance of individual factors for the effective achievement of one's own goals.

The general characteristics of NGO leaders in relation to the traits considered in this study require a separate comment. These leaders are characterised by high and moderate intensities of such traits. This seems understandable in the context of the role they assume and the tasks with which this role is connected. In other words, assuming the role of leader may be subject to an individual selection mechanism that favours people with a suitably high intensity of such traits. It is possible that these traits are amplified while carrying out tasks connected with managing an organisation.

Finally, it should be noted that the results of the conducted analysis allow us to formulate predictions concerning the establishment of cooperation with rural gmina offices, depending on the intensity of social competences, locus of control and the education of NGO leaders. This could prove useful in the diagnosis of leaders' capabilities, so that suitable action to reinforce their individual potential, which determines cooperation between their organisations and rural gmina offices, can be taken.

We would like to stress that all the models we tested displayed good fit. This is clearly formulated in the text. This means that all the considered variables played a role in the fitting process; however, those most important for cooperation are included in the final model. Thus, the fact that a single variable, such as sex, was not a significant predictor in the present configuration of variables does not mean that it will also be irrelevant in a different study, and in a different context.

Several limitations of the study should be noted. The first is the reduction in sample size due to insufficient data and outlier results. However, it was necessary for the continuation of analyses, with the minimisation of biases caused by the problematic results of individual replies and difficulty in gaining data from the population. Despite this fact, the estimation error is possible to define and control, as described in Method section.

The second limitation involves the use of the interview questionnaire method and the analyses based on the declarations made by respondents, which (due, for instance, to the possible interviewer effect) may not reflect reality. In other words, it is possible that respondents all too often declared their cooperation with gmina offices in accordance with the NPG model. However, as noted earlier, the advantages of this research method were the deciding factors in rejecting the analysis of existing documents at the disposal of NGOs or gmina offices. The practices of gmina offices and NGOs may differ from the content of such documents. Moreover, these documents do not reflect the specific character of rural communities in which (as we have mentioned) informal contacts, agreements between NGO and gmina office leaders, are more significant than written agreements. Besides, obtaining such documents (especially from gmina offices) is an immensely difficult organisational task, and often just asking for the documents results the leaders' reluctance to participate in the study.

Finally, we realise that there are many conditions of cooperation between rural gmina offices and non-governmental organisations. In the article we only analysed those connected with traits of leaders of rural non-governmental organisations.

In particular, the sociocultural conditions of cooperation between rural NGOs (in accordance with the New Public Governance concept) and public institutions deserve analysis. Raising these issues is a very ambitious and complex task, as it requires taking Polish history into account. Firstly, the partition period should be considered, when Poland lost its independence, and the policies of the invading powers with respect to rural residents' freedom of association. Secondly, the socialist period should also be taken into account, when such activity was also not fostered, but during which the existing traditional forms of rural residents association were present. Moreover, in such analyses it is of key importance to focus on contemporary consequences of historical conditions, which can influence cooperation between rural gmina offices and NGOs. One such consequence is clientelism, which is mentioned in the article. Taking into consideration all of this, undertaking 
such research poses a scientific challenge, the details of which cannot be described in this article.

Acknowledgements Many thanks to the sponsor of the research project entitled, 'Local systems of social innovations in rural areas' (Grant: 015/19/D/HS6/00690)—National Science Centre from Poland and to the reviewers for their critique and suggestions. We are, however, ultimately responsible for the contents of this article.

Authors' Contribution Katarzyna Karolina Zajda was involved in conceptualisation (lead), funding acquisition (lead), methodology (supporting), writing original draft (equal), and Slawomir Pasikowski contributed to conceptualisation (supporting), formal analysis (lead), methodology (lead), writing original draft (equal).

Funding This study was funded by the National Science Centre [Poland] (Research Project Reference No.: 015/19/D/HS6/00690, DEC-2015/19/D/HS6/00690, Contract No. UMO-2015/19/D/HS6/ 00690).

\section{Compliance with Ethical Standards}

Conflict of interest The authors declare that they have no conflict of interest. Additionally, the authors confirm that this work is original and has not been published elsewhere, nor is it currently under consideration for publication elsewhere.

Open Access This article is distributed under the terms of the Creative Commons Attribution 4.0 International License (http://crea tivecommons.org/licenses/by/4.0/), which permits unrestricted use, distribution, and reproduction in any medium, provided you give appropriate credit to the original author(s) and the source, provide a link to the Creative Commons license, and indicate if changes were made.

\section{References}

AbouAssi, K., Makhlouf, N., \& Whalen, P. (2016). NGOs' resource capacity antecedents for partnerships. Nonprofit Management \& Leadership, 26(4), 435-451.

Act of law of April 24th 2003 on Public Benefit and Volunteer Work (Consolidated text, last amended on 16 October 2016, Journal of Laws from 2016, item 1817).

Adamiak, P., Charycka, B., \& Gumkowska, M. (2016). Kondycja sektora organizacji pozarzadowych $w$ Polsce. Raport $z$ badań. Warszawa: Stowarzyszenie Klon/Jawor.

Aggleton, P. J., \& Whitty, G. (1985). Rebels without a cause? Socialization and subcultural style among the children of the new middle classes. Sociology of Education, 58(1), 60-72.

Ames, D. R. (2007). Assertiveness expectancies: How hard people push depends on the consequences they predict. Journal of Personality and Social Psychology, 95(6), 1541-1557.

Ames, D. R., \& Flynn, F. J. (2007). What breaks a leader: The curvilinear relation between assertiveness and leadership. Journal Personality and Social Psychology, 92(2), 307-324.

Apter, M. J. (1982). The experience of motivation. The theory of psychological reversals. London: Academic Press.

Apter, M. J. (2001a). An introduction to reversal theory. In M. J. Apter (Ed.), Motivational styles in everyday life. Washington: American Psychological Association.

Apter, M. J. (2001b). Reversal theory as a set of propositions. In M. J. Apter (Ed.), Motivational styles in everyday life. Washington: American Psychological Association.
Banyan, M. (2014). Civic capacity assessment framework. In D. Morgan \& B. Cook (Eds.), New public governance. A regimecentred perspective. London: Routledge.

Baumeister, R. F. (1982). A self-presentational view of social phenomena. Psychological Bulletin, 91, 3-26. https://doi.org/ 10.1037/0033-2909.91.1.3.

Blickle, G. (2003). Some outcomes of pressure, ingratiation, and rational persuasion used with peers in the workplace. Journal of Applied Social Psychology, 33, 648-665.

Bohra, K. A., \& Pandey, J. (1984). Ingratiation toward strangers, friends, and bosses. The Journal of Social Psychology, 122, 217-222. https://doi.org/10.1080/00224545.1984.9713483.

Brehm, J. (1966). A theory of psychological reactance. London: Academic Press.

Brehm, S. S., \& Brehm, J. (1981). Psychological reactance. A theory of freedom and control. London: Academic Press.

Bryan, E., \& Sapeha, H. (2015). Are non-government policy actors being heard? Assessing new public governance in Tyree Canadian provinces. Canadian Public Administration, 58(2), 249-270.

Bukobza, G. (2009). Relations between rebelliousness, risk-taking behavior, and identity status during emerging adulthood. Identity: An International Journal of Theory and Research, 9, 159-177.

Chimiak, G. (2016). The growth of non-governmental development organizations in Poland and their cooperation with Polish aid. Warszawa: IFiS PAN.

DeLamater, J. D., \& Myers, D. J. (2011). Social psychology. Belmont: Wadsworth Cengage Learning.

Deluty, R. H. (1979). Children's action tendency scale: A self-report measure of aggressiveness, assertiveness, and submissiveness in children. Journal of Consulting and Clinical Psychology, 47(6), 1061-1071.

Dowd, E. T., Milne, Ch R, \& Wise, S. L. (1991). The therapeutic reactance scale: A measure psychological reactance. Journal of Counseling and Development, 69(6), 541-545.

Działek, J. (2014). Is social capital useful for explaining economic development in Polish regions? Geografiska Annaler. Series B, Human Geography, 96(2), 177-193.

Ellis, A. P. J., West, B. J., Ryan, A. M., \& DeShon, R. P. (2002). The use of impression management tactics in structured interviews: A function of question type? Journal of Applied Psychology, 87, 1200-1208. https://doi.org/10.1037/0021-9010.87.6.1200.

Fagan, A. (2006). Transnational aid for civil society development in post-socialist Europe: Democratic consolidation or a new imperialism? Journal of Communist Studies and Transition Politics, 22(1), 115-134.

Fernandes, J. V. (1988). From the theories of social and cultural reproduction to the theory of resistance. British Journal of Sociology, 9(2), 169-180.

Foster, M. K., \& Meinhard, A. G. (2002). A regression model explaining predisposition to collaborate. Nonprofit and Voluntary Sector Quarterly, 31(4), 549-564.

Fotaki, M. (2011). Towards developing new partnerships in public services: Users as consumers, citizens and/or co-producers in health and social care in England and Sweden. Public Administration, 89(3), 933-955.

Furmankiewicz, M. (2012). LEADER + territorial governance in Poland: Successes and failures as a national choice effect. Tijdschrift voor Economische en Sociale Geografie, 103(3), 261-275.

Furmankiewicz, M., Janc, K., \& Macken-Walsh, A. (2016). The impact of EU governance and rural development policy on the development of the third sector in rural Poland: A nation-wide analysis. Journal of Rural Studies, 43, 225-234. 
Furmankiewicz, M., \& Macken-Walsh, A. (2016). Government within governance? Polish rural development partnerships through the lens of functional representation. Journal of Rural Studies, 46, 12-22.

Goffman, E. (1961). Asylums: Essays on the social situation of mental patients and other inmates. New York: Doubleday Anchor.

Gordon, R. A. (1996). Impact of ingratiation on judgments and evaluations: A meta-analytic investigation. Journal or Personality and Social Psychology, 71, 54-70.

Hassan, M., Bashir, S., \& Abbas, S. (2017). The impact of project managers' personality on project success in NGOs: The mediating role of transformational leadership. Project Management Journal, 48(2), 74-87.

Hosmer, D. W., Lemeshow, S., \& Sturdivant, R. X. (2013). Applied logistic regression. New Jersey: Wiley.

Jones, E. E., \& Wortman, C. B. (1973). Ingratiation: An attributional approach. Morristown: General Learning Press.

Karolewski, I. (2016). Protest and participation in post-transformation Poland: The case of the Committee for the Defense of Democracy (KOD). Communist and Post-communist Studies, 49, 255-267.

King, N. (2004). Social capital and nonprofit leaders. Nonprofit Management and Leadership, 14(4), 471-486.

Kleinbaum, D. G., \& Klein, M. (2010). Logistic regression. A selflearning text. New York: Springer.

Knowles, E. S., \& Riner, D. D. (2007). Omega approaches to persuasion: Overcoming resistance. In A. R. Pratkanis (Ed.), The science of social influence. New York: Psychology Press.

Kotarba, B. (2015). The principles of partnership in selected activities of local governments. In A. Pawłowska \& A. Gąsior-Niemiec (Eds.), Partnerships in the public sector. Scholar: Warsaw.

Kovach, I., \& Kucerova, E. (2006). The project class in Central Europe: The Czech and Hungarian cases. Sociologia Ruralis, 46, $3-21$.

Łabędź, K. (2015). Awareness factors of interpersonal cooperation in Poland. In A. Pawłowska \& A. Gạsior-Niemiec (Eds.), Partnerships in the public sector. Scholar: Warsaw.

Lindsay, C., Osborne, S., \& Bond, S. (2014). The new public governance and employability services in an era of crisis: Challenges for third sector organizations in Scotland. Public Administration, 92(1), 192-207.

Macken-Walsh, Á., \& Curtin, C. (2012). Governance and rural development: The case of the Rural Partnership Programme (RPP) in post-socialist Lithuania. Sociologia Ruralis, 53(2), 246-264.

Majerova, V. (2009). Local initiatives functioning as a condition of rural development of the Czech countryside. Eastern European Countryside, 15, 127-149.

Marquardt, D., Möllers, J., \& Buchenrieder, G. (2012). Social networks and rural development: LEADER in Romania. Sociologia Ruralis, 52, 398-431.

Matczak, A., Jaworowska, A., Fecenec, D., Stańczak, J., \& Bitner, J. (2009). Człowiek $w$ Pracy. Podręcznik. Warszawa: Pracownia Testów Psychologicznych Polskiego Towarzystwa Psychologicznego.

Matczak, A., \& Martowska, K. (2013). Profil Kompetencji Spotecznych. PROKOS. Podrecznik. Warszawa: Pracownia Testów Psychologicznych Polskiego Towarzystwa Psychologicznego.

McCrae, R. R., \& Costa, P. T. (1987). Validation of the five-factor model of personality across instruments and observers. Journal of Personality and Social Psychology, 52(1), 81-90.

McCrae, R. R., \& Costa, P. T. (2008). Empirical and theoretical status of the five-factor model of personality traits. In G. J. Boyle, G. Matthews, \& D. H. Saklofske (Eds.), The SAGE handbook of personality theory and assessment: Personality theories and models (Vol. 1). Thousand Oaks: SAGE.
McCrae, R. R., \& John, O. P. (1992). An introduction to the fivefactor model and its applications. Journal of Personality, 60(2), $175-215$.

McDermott, R. (1988). Measuring rebelliousness: The development of the negativism dominance scale. In M. J. Apter, J. H. Kerr, \& M. P. Cowles (Eds.), Progress in reversal theory. Amsterdam: Elsevier.

McDermott, R. (2001). Rebelliousness. In M. J. Apter (Ed.), Motivational styles in everyday life. Washington: American Psychological Association.

Mikušova Meričkova, B., Nemec, J., \& Svidronova, M. (2015). Cocreation in local public services delivery innovation: Slovak experience. Lex Localis-Journal of Local Self-Government, 13(3), 521-535.

Mitchell, G., O'Leary, R., \& Gerard, C. (2015). Collaborations and performance: Perspectives from public managers and NGO leaders. Public Performance \& Management Review, 38, 684-716.

Morgan, D., \& Cook, B. (Eds.). (2014). New public governance. A regime-centred perspective. London: Routledge.

Morgan, D., \& Shinn, C. (2014). The foundations of new public governance. In D. Morgan \& B. Cook (Eds.), New public governance. A regime-centred perspective. London: Routledge.

O'Connell, A. A. (2006). Logistic regression models for ordinal response variables. Thousand Oaks: SAGE Publishing.

Osborne, W. J. (2015). Best practices in logistic regression. Los Angeles: Sage Publication.

Osborne, S., Radnor, Z., \& Strokosch, K. (2016). Co-production and the co-creation of value in public services: A suitable case for treatment? Public Management Review, 18, 639-653.

Osborne, S., \& Strokosch, K. (2013). It takes two to tango? Understanding the co- production of public services by integrating the services management and public administration perspectives. British Journal of Management, 24, 31-47.

Pasikowski, S. (2016a). Validation of the questionnaire of readiness to resist against social impact. Perspective of applications in academic education contexts. Czasopismo Pedagogiczne/The Journal of Pedagogy, 3, 135-151.

Pasikowski, S. (2016b). Kwestionariusz Gotowości Przeciwstawiania się. Podręcznik. Przeglad Badań Edukacyjnych/Educational Studies Review, 23a (special number).

Pawłowska, A. (2017). Territorial partnerships in rural regions-NeoInstitutional perspective. Polish Sociological Review, 1(197), 95-108.

Pawłowska, A., \& Gąsior-Niemiec, A. (Eds.). (2015). Partnerships in the public sector. Scholar: Warsaw.

Pestoff, V. (2012). Co-production and third sector social services in Europe: Some concepts and evidence. Voluntas. International Journal of Voluntary and Nonprofit Organizations, 23, 1102-1118.

Pestoff, V., Brandsen, T., \& Verschuere, B. (Eds.). (2012). New public governance, the third sector and co-production. London: Routledge.

Powell, M., Greener, I., Szmigin, I., Doheny, S., \& Mills, N. (2010). Broadening the focus of public service consumerism. Public Management Review, 12(3), 323-339.

Radnor, Z., \& Osborne, S. P. (2013). Lean: A failed theory for public services? Public Management Review, 15(2), 265-287.

Riggio, R. (1986). Assessment of basic social skills. Journal of Personality and Social Psychology, 51(3), 649-660.

Riggio, R., \& Taylor, S. (2000). Personality and communication skills as predictors of hospice nurse performance. Journal of Business and Psychology, 15(2), 351-359.

Riggio, R., Throckmorton, B., \& Depaola, S. (1990). Social skills and self-esteem. Personality and Individual Differences, 11(8), 799-804. 
Soomro, A. B., Salleh, N., Mendes, E., Grundy, J., Burch, G., \& Nordin, A. (2016). The effect of software engineers' personality traits on team climate and performance: A systematic literature review. Information and Software Technology, 73, 52-65.

Sørensen, E., \& Torfing, J. (2015). Enhancing public innovation through collaboration, leadership and New Public Governance. In A. Nicholls, J. Simon, \& M. Gabriel (Eds.), New frontiers in social innovation research. Basingstoke: Palgrave Macmillan.

Spisak, B. R., Grabo, A. E., Arvey, R. D., \& Van Vugt, M. (2014). The age of exploration and exploitation: Younger-looking leaders endorsed for change and older-looking leaders endorsed for stability. The Leadership Quarterly, 25(5), 805-816.

Stenner, P., \& Marshal, H. (1995). A Q methodological study of rebelliousness. European Journal of Social Psychology, 25(6), 621-636.

Stump, K., Ratliff, J., Wu, Y., \& Hawley, P. (2010). Theories of social competence from the top-down to the bottom-up: A case for considering foundational human needs. In J. L. Matson (Ed.), Social behavior and skills in children. New York: Springer.

Sułek, A. (2013). Civil experience, activities for the benefit of the community and civil skills. In J. Czapiński \& T. Panek (Eds.), Social diagnosis 2013. Objective and subjective quality of life in Poland (pp. 285-295). Warsaw: Contemporary Economics.

Thomas, A., Donnell, A. J., \& Buboltz, W. C., Jr. (2001). The Hong psychological reactance scale: A confirmatory factor analysis. Measurement and Evaluation in Counseling and Development, $34(1), 2-13$.

Torfing, J., \& Triantafillou, P. (2013). What's in a name? Grasping new public governance as a political-administrative system. International Review of Public Administration, 18(2), 9-25.

Unceta, A., Castro-Spila, J., \& Fronti, J. G. (2016). Social innovation indicators. Innovation: The European Journal of Social Science Research, 29(2), 192-204. van Tulder, R., Seitanidi, M. M., Crane, A., \& Brammer, S. (2016). Enhancing the impact of cross-sector partnerships. Four impact loops for channeling partnership studies. Journal of Business Ethics, 135, 1-17.

Van Vugt, M., \& Grabo, A. E. (2015). The many faces of leadership: An evolutionary-psychology approach. Current Directions in Psychological Science, 24(6), 484-489.

Voorberg, W. H., Bekkers, V. J. J., \& Tummers, L. G. (2015). A systematic review of co-creation and co-production. Embarking on the social innovation journey. Public Management Review, 17(9), 1333-1357.

Wiesel, F., \& Modell, S. (2014). From new public management to new public governance? Hybridization and implications for public sector consumerism. Financial Accountability \& Management, 30(2), 175-205.

Zajda, K. (2014). Problems of functioning of Polish local action groups from the perspective of the social capital concept. Eastern European Countryside, 20, 73-98.

Zajda, K. (2017). Collaboration between rural non-governmental organisations and local entities and their potential for implementing social innovations. The example of organizations from Lubelskie Province. Acta Innovations, 24, 14-21.

Zajda, K., \& Kretek-Kamińska, A. (2013). Professionalisation and economization of rural NGOs and the activity of their members. An example of local action groups from Wielkopolska. Journal of Agribusiness and Rural Development, 1(27), 249-260.

Zawadzki, B., Strelau, J., Szczepaniak, P., \& Śliwińska, M. (1997). Inwentarz Osobowowści NEO-FFI. In P. T. Costy Jr. \& R. R. McCrae (Eds.), Adaptacja polska. Warszawa: Pracownia Testów Psychologicznych Polskiego Towarzystwa Psychologicznego.

Zimbardo, P. (2008). The Lucifer effect: Understanding how good people turn evil. New York: Random House. 